THURSDAY, JANUARY 8, I880

\section{THE TECHNICAL UNIVERSITY QUESTION}

$T \mathrm{HE}$ correspondence which has appeared during the 1 month of December in the columns of the Times concerning the question of a Metropolitan Technical University, has revived a question upon which we have more than once spoken in these columns, and of which we shall hear more hereafter. It is quite evident that the promoters of the City and Guilds of London Institute for the Advancement of Technical Education meet with many great and unforeseen difficulties in the way of pushing into execution their laudable project for applying some of the vast funds they have inherited from the Trade Guilds of the past to the purpose of promoting the elevation of trade by science. It is equally evident that they will not abandon their projects without a very considerable effort, especially now that the pressure of public opinion is beginning to bear upon the question and to aid them in their demand. No one probably denies or doubts the legal right of the City Companies to the funds which have thus come down to them. Probably also no one denies or doubts that the law-making power which gave them these legal rights can take them away and can force them to hand over, if need be, to the advancement of Technical Education at large, the wealth which they have ceased to apply to the advancement of Technical Education within their own borders. Two years ago a very definite scheme in this direction was launched by the provisional Committee appointed by some of the Guilds. Recognising the moral obligation upon them to use their funds for the advancement of their respective industries, some dozen out of the eighty City Companies agreed to devote a certain yearly sum for this purpose. They even went so far as to invite a number of distinguished men of science to write reports on the best way of attaining the ends in view, and eventually they embodied their suggestions in a report which was characterised by two main propositions: firstly, to establish local technical schools which should be accessible to artisans; secondly, to found a central institution, chiefly for training technical teachers and scholars of exceptional promise. This was two years ago; and in the mean time so little has been done, that some of those who have taken an active part in the earlier stages, begin to be impatient at the little substantial progress made.

A note of dissatisfaction of this nature was heard at the beginning of the month of December, and gave rise to the discussion in the Times, to which we have alluded. To understand the merits of the controversy it will be necessary to go back to the beginning. The correspondence arose out of some remarks made by Prof. Huxley when presiding at the meeting of the Society of Arts on December 3, at which a paper on apprenticeship was read by Prof. Silvanus Thompson, of Bristol, and to which a paragraph was devoted in NATURE, vol. xxi. p. 139. Prof. Thompson's paper, which appeared in the Journal of the Society of Arts for December 5, and which has been reprinted in pamphlet form, was devoted to a discussion of the relation between apprenticeship and technical education; and after laying down the general VoL. XxI, -No. 532 principles of a scientific and rational system of apprentice training, pointed out that the "lower technical," or " industrial" training which is needed for the forming of good workmen, cannot exist in any effective degree until there is some provision made for the inigher technical training analogous to that of the great technical schools of Germany and France, which would qualify a superior class to become on the one hand foremen and masters, and on the other teachers in technical schools. In short, Prof. Thompson's argument was that there could be no growth of technical schools for the artisan without a central technical university to train teachers for such schools.

In the discussion which ensued Prof. Huxley made some pungent remarks upon the delays which had arisen over the project of the Guilds and Companies of the City of London, who had consulted him some time back concerning their proposal to found a Central Institution or Technical College, and who, two years ago had empowered him to make known their good intentions. It was time, he thought, that those good intentions bore fruit. It would be an utter scandal if one shilling were asked for out of the general revenue for this purpose, at least so far as London was concerned, for the Livery Companies were in possession of the enormous funds inherited along with the ancient traditions of the crafts from the old Guilds of London, which were established to aid their respective trades-funds which they were morally, if not legally, bound to apply to the advancement of Technical Education.

Prof. Huxley's remarks were not, however, suffered to pass unchallenged. In the Times of December $9 \mathrm{Mr}$. J. H. Crossman condemned Prof. Huxley and those who act with him as somewhat impatient and hasty in their proposals.

To this letter Prof. Huxley replied a few days later in a most admirably conceived and no less successfully worded letter. What had been proposed was simply the establishment of local technical schools accessible to the artisans, and a Central Institution chiefly for the training of teachers and of scholars of exceptional capacity; and he added the very pertinent query: "Do the Livery Companies of London intend to carry out any general scheme of Technical Education such as that adopted by their own Committee, or do they not ?"

Mr. Owen Roberts, one of the Honorary Secretaries of the City and Guilds Institute, replied to the point raised by Prof. Huxley's letter, asking whether he was aware of the negotiations which had been going on between the City and Guilds Institute, and the Lords Commissioners of the Exhibition of $185 \mathrm{I}$, for a piece of land on the South Kensington estate as a site for a central institution, and stating that the only reason why these negotiations had not been definitely concluded, was that lately the Commissioners had put forward certain requirements, as a condition of their grant of a site, which the Livery Companies have not considered to be consistent with their independence of action. Hence the regretted delays, which had not, however, debarred the Institute from proceeding with one very important section of its work, namely, the promotion of local schools for artisans.

Following hard on Mr. Roberts's letter, there appeared in the Times of December 27 a communicated article 
giving a careful and detailed history of the various schemes considered by the City and Guilds Institute, which may be broadly stated as being three in number. The first of these schemes, proposing to build a central institution upon a site on the Corporation lands on the Thames Embankment, has been dismissed as essentially too costly. The second, the proposal to obtain a site from the Commissioners of the South Kensington Estate, is in abeyance since the ancient free "spirit" of the Companies leads them to regard as distasteful either that the Commissioners should be directly represented on the managing body of the Central Institution, or that, as an alternative, the chief scientific bodies of the nation should have the right of being represented on it. The third scheme, which apparently does not stand a much better chance of success than its predecessors, though having many points in its favour, was a proposal to buy the palatial mansion built by Baron Grant at Kensington, with its seven acres of ground, and convert it into a building for a Central Institution by slight but suitable alterations in its interior arrangements, thus obtaining capital laboratories and lecture theatres. But the unreasoning outcry raised against the site simply because it was in the west, and not in some equally inaccessible situation in the north or in the east, has been so loud in its tones that we believe the project has virtually been abandoned. At least so the semi-official article in the Times would lead us to imagine. Prof. Huxley has, however, had a last word on the matter. He cannot quite agree in the view that the guarantees asked by the Lords Commissioners are so unreasonable as the Livery Companies think them. In his second letter of the 29 th ult. he says that if he is rightly informed, they amount to being guarantees firstly of sufficiency and permanency of endowment, and secondly of proper government; the desire of the Commissioners in reserving the right of nominating two or three members of the governing body being merely that they may insure the presence amongst the representatives of the city magnates that small number of "educational experts." To which Mr. Roberts quietly rejoined that educational experts differed considerably in the advice they tendered, and that the principal point of objection lay in the proposal that the two or three persons nominated by an exterior authority should be the only permanent members of a governing body the majority of whom were continually going off by rotation.

It is not our place to pronounce judgment upon the conflicting views which have been maintained concerning the conditions imposed by the Commissioners in their offer of a site. If Prof. Huxley's information is correct, it is hard to see how or why the independence of the Guilds, or of the Institute they have founded, should be impaired by the presence on the governing body of such men as, say, Mr. Lyon Playfair, or Mr. Mundella, or perhaps even Prof. Huxley himself. If, on the other hand, the Livery Companies have some further knowledge or insight than Prof. Huxley has, it would certainly be well if they would explain what it is that is incompatible with their ancient liberties, and would suggest some alternative course, which, while reserving them all reasonable liberty of action, should attain the ends for which guarantees are desired.

The most painful aspect of the whole controversy is one which does not come to the surtace in this correspondence, but which is nevertheless a very real one. There is a Jarge section of the outside public who take a deep and increasing interest in the question of technical education, and who have watched the present scheme from its first inception with something more than curiosity. They cannot understand that any body of men really intending to carry out a project such as that which was made public two years ago could permit such endless delays, such interminable cross-p'urposes, such haggling over different schemes, as have been lately witnessed. They begin to fear that all these things are done with a purpose, and that the delays are interested, and the rival schemes manufactured to serve some less noble end. Whether such persons are right or wrong, all these whispers would be at once silenced by a few unmistakable signs of real progress, such as we have looked for in vain. The public knows well enough that the organisation of the City Guilds as they are is a blot upon an intelligent community; that they have ceased in all but name to represent the trades for the sake of which and out of which they arose. It knows full well that their unfathomed funds are not applied to the purpose of elevating and improving their respective crafts, whatever else they may be applied to. And it is quite prepared to say with emphasis when the moment arrives that if reform does not come from within it must come from without. The first step, if such measures must come, will doubtless be the appointment of a Royal Commission of Inquiry. What the second might be he must be bold who would predict.

The announcements made two years ago were hailed as a note of progress, indicating the probability that wiser counsels would prevail, and that the needed reform was to be brought about quietly and harmoniously from within. But the project for founding a Central Technical College is as far from realisation as ever, and the hopes raised have been sorely disappointed. Men of scientific habits and of business aptitudes are alike getting tired of the endless delays and fruitless negotiations that have taken place. And there are, we suspect, many who, on learning how one scheme after another has fallen through for want of unanimity of purpose to carry it out, will be quite ready to think that it was not without good cause that Prof. Huxley asked: Do the Livery Companies of London intend to carry out any general scheme of Technical Education such as that adopted by their own Committee, or do they not?

\section{OSTEOLOGY OF MAN}

Catalogue of the Specimens Illustrating the Osteology and Dentition of Vertebrated Animals, Recent and Extinct, contained in the Museum of the Royal College of Surgeons of England. By William Henry Flower, Conservator of the Museum. Part I. Man. (London: David Bogue, r879.)

$\mathrm{T}$ is now twenty-five years ago since Prof. Owen, the 1 then Conservator of the Museum of the Royal College of Surgeons, completed the last volume of the catalogue of the osteological collection. Since that time the additions to the Museum have been so numerous and 